\title{
Hydrocodone Measurement
}

National Cancer Institute

\section{Source}

National Cancer Institute. Hydrocodone Measurement. NCI Thesaurus. Code C74879.

The determination of the amount of hydrocodone present in a sample. 